Scientific Electronic Archives

Issue ID: Sci. Elec. Arch. Vol. 14 (12)

December 2021

DOI: http://dx.doi.org/10.36560/141220211487

Article link: https://sea.ufr.edu.br/SEA/article/view/1487

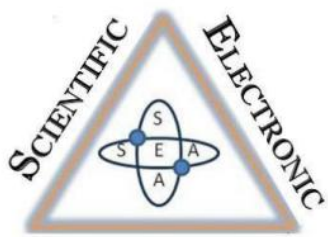

ArChives

ISSN 2316-9281

\title{
Cultural treatments in pineapple crop. Management for high yield - Review
}

\author{
Corresponding author \\ Reginaldo Almeida Andrade \\ Universidade Federal de Rondônia \\ reginaldo.andrade@unir.br \\ Rychaellen Silva de Brito \\ Universidade Federal do Acre \\ Rosiney França Mendes \\ Universidade Federal do Acre
}

Romeu de Carvalho Andrade Neto

Empresa Brasileira de Pesquisa Agropecuária

\begin{abstract}
Several factors influence in the vegetative development, yield and quality of pineapple fruits, among which the cultural treatments adopted throughout the production cycle stand out, mainly weed control, mineral nutrition, irrigation and induction artificial flowering. The purpose of this review was to present the main advances in research on cultural treatments in the cultivation of pineapple (Ananas comosus L. Merril) and their effects on yield and fruit quality. Current research shows that interventions for weed management, through chemical control with herbicides or the adoption of organic or inorganic soil cover are strategies that can be adopted by producers who seek to reduce labor costs and provide good conditions for plant development. The use of mulching is a promising and effective practice, given the cost reduction with polluting herbicide applications and improvement of the physicochemical quality of the soil. Regarding mineral nutrition, pineapple is a rustic plant, tolerant to soils with moderate acidity and low levels of nutrients in the soil, however, liming and fertilization are essential for crops where high yields are sought. In the same way, it is verified that the pineapple, even being a CAM metabolism plant, tolerant to situations of water stress, is highly responsive to irrigation, which provides improvements in the vegetative and reproductive development of the plant. Another essential management practice in pineapple crops is artificial floral induction, a practice that aims to synchronize the flowering period, facilitate harvesting and ensure a consumer market in times when the supply of fruit is scarce.
\end{abstract}

Keywords: Ananas comosus, floral induction, irrigation, mineral nutrition, mulching, soil management.

\section{Introduction}

The pineapple (Ananas comosus L. Merr.), is a perennial monocot originating in South America, and most representative member of the Bromeliaceae family (Crestani et al., 2010; Neri et al., 2021). It is mainly cultivated in tropical and subtropical regions (Djido et al., 2021), with Costa Rica, Philippines, Brazil, Thailand and Indonesia being the main world producers. In terms of global importance, it ranks second among the main tropical fruit trees, behind only the mango (FAO et al., 2019).

Because it has an eccentric flavor and intense aroma, pineapple is much appreciated, and can be consumed fresh or processed, in the form of juices, syrups, liqueurs, wines, in syrup, candied, and in the making of sweets, ice creams, creams, cakes, among others (Crestani et al., 2010; Teixeira et al., 2020). It is rich in phenolic compounds such as flavonoids, carotenoids and hydroxycinnamic acids (Neri et al., 2021), vitamins A, B1, B6 and C, as well as nutrients such as copper, manganese and fibers (Pérez et al., 2011).

In Brazil, its cultivation is carried out in all regions, and in 2018, the national production went 2.65 million tons, with the states of Pará, Paraíba, Minas Gerais and Bahia leading as the largest producers (IBGE, 2020). Fao data (2019) indicate that the average Brazilian productivity is $24.19 \mathrm{t}$ ha ${ }^{1}$, an amount lower than the averages of other major 
producers, such as Indonesia, with $115 \mathrm{t} \mathrm{ha}^{-1}$, Costa Rica, with $68 \mathrm{t} \mathrm{ha}^{-1}$ or Mexico with $47.68 \mathrm{t} \mathrm{ha}^{-1}$. This fact is associated with the low level of technological investment adopted in most producing regions and inefficient management throughout the production cycle.

The crop has a long cycle, divided between the vegetative phases, ranging from planting to floral differentiation, and lasts from 8 to 12 months; the reproductive phase, or fruit formation, which lasts between 5 and 6 months; and the propagative phase, or seedling formation, which overlaps the reproductive phase and can last between 4 and 10 months, depending on the cultivar (Reinhardt, 2000). Its initial growth is slow, and several factors can change the duration of these phases, and influence the production and quality of harvested fruits (Maia et al., 2018; Valverde \& Chaves, 2020).

Among these factors, we highlight the climate, the choice of cultivar, the planting density and the various cultural treatments adopted throughout the production cycle, mainly soil management, mineral fertilization, weeds control, irrigation and artificial induction of flowering. Therefore, the knowledge and application of these practices is essential to improve the cultivation environment and productive indicators in pineapple crops (Matos et al., 2014; Espinosa et al., 2017; Renton \& Chauhan, 2017).

Because it has a superficial root system, pineapple is very vulnerable to interference from weeds, which compete for water, light and nutrients (Valverde \& Chaves, 2020). Chemical control with herbicides, pre and post emergent is the most adopted in commercial pineapple crops, and has as advantages the high efficiency and low cost. However, it requires caution during application, since the contact of the chemical agent with plants can cause phytotoxicity and impair development (Carvalho et al., 2018). Another viable strategy is the adoption of soil cover, in the lines and between rows of cultivation, which in addition to suppressing the occurrence of weeds, improves the chemical, physical and biological properties of the soil (Renton \& Chauhan, 2017).

Even though it is a rustic plant, which develops in soils with low fertility, and presents crassulaceous acid metabolism (CAM), with high efficiency in water use, mineral fertilization and the use of supplementary irrigation during drought periods is essential to achieve high yields (Matos et al., 2014). Regarding the transition from vegetative to reproductive, under natural conditions, pineapple flowering is slow and uneven, and can be influenced by conditions of low temperatures and short photoperiod (Bartholomew et al., 2003), hindering phytosanitary treatments and prolong the harvest. Thus, the hormonal induction of flowering is a management strategy that should be adopted in order to synchronize floral differentiation, besides enabling the direction of the harvest for times favorable to commercialization (Espinosa et al., 2017; Julius et al., 2017).

In this context, the objective of this review is to bring the main advances in research on cultural treatments in the cultivation of pineapple (Ananas comosus L. Merrill), mainly addressing the aspects related to soil management and weeds control, mineral nutrition, irrigation, and artificial flowering induction, and with this, generate information that can be applied in commercial pineapple plantations that seek high yields.

\section{Soils for pineapple production}

The diagnosis of soil physical attributes and the monitoring of their variations that occur during the dry and rainy seasons is essential in the planning for the installation of pineapple plantations. Although the plant develops in the most diverse soil conditions, from sandy, to those with high clay contents, the crop requires environments with good aeration and drainage, not tolerating soils subject to soaking and excessive moisture.

To achieve high yields, it is recommended to plant in areas with medium texture soils, between $15 \%$ to $35 \%$ clay and more than $15 \%$ sand, with effective depth above $70 \mathrm{~cm}$, and $\mathrm{pH}$ between 4.5 and 5.5. However, pineapple can be grown in soils with clayey texture, as long as they present good aeration and drainage conditions. This is because, under conditions of excessive moisture and soil soaking, the leaves become thinner and more yellowish, and root rot and plant death may occur as a result of the attack of phytopathogenic fungi (Teixeira et al., 2020).

Reinhardt (2000) advise that pineapple planting should not be carried out in compacted soils, either by natural processes, or induced by anthropic action. The author stresses that the development of pineapple is favored in well-structured soils with good organic matter content, and that high natural fertility is desirable, since it reduces the costs of nutrient applications through fertilization.

Planting areas should preferably be flat or with a low slope, up to $5 \%$, as it facilitates cultural treatments, in addition to being less susceptible to erosion. Planting in areas with very accentuated topography can be carried out, provided that conservation practices are adopted (Teixeira el al., 2020), such as terracing, contour lines and living ground cover, with forage plants, or dead plants, with organic residues or inorganic, in order to avoid the entrainment of particles and the loss of soil and nutrients.

\section{Weeds control}

Weeds interference can reduce the productivity and quality of pineapple fruits, and it is necessary to take some control method to avoid losses and increase in production costs. The control can be performed through various management strategies, such as manual weeding, chemical control with herbicides, or through soil cover, with 
organic residues, or inorganic materials in rows and between rows of cultivation, or combinations of two or more of these methods (Maia et al., 2012).

Manual weeding was the first methods used in pineapple crops, and is still widely adopted in small rural properties. However, this practice has become obsolete, given the excessive costs with labor, since between 10 and 12 interventions are needed throughout the cultivation cycle, which may represent more than $50 \%$ of production costs (Maia et al., 2012).

The application of herbicides, pre- and postemergence, or a combination of both, are fast and efficient methods, reducing labor costs and keeping the crop free of weeds. Pre-emergence herbicides prevent weeds from germinating for 60 to 90 days, increasing the interval between applications and reducing intervention costs. The post-emergent ones only reach emerged plants, not affecting the soil seed bank (Model \& Favreto, 2010). However, the use of these chemical agents requires some care, since the contact of the product applied with pineapple plants is inevitable, especially at high planting densities, which can cause phytotoxicity to the crop and compromise productivity (Carvalho et al., 2018).

In Brazil, there are 200 herbicides registered for pineapple crop, formulated from seven chemical groups, Ametrin, Bromacil, Cletodim, Diuron, Simazina and Sulfentrazona, in addition to several elaborated from combinations of these groups (Agrofit, 2021). Table 1 shows the chemical groups, the type of application and dose, in addition to the mechanism of action in weeds.

Table 1. Herbicides registered in the Ministry of Agriculture, Livestock and Supply (MAPA) for use in the control of pineapple weeds - 2021.

\begin{tabular}{lccc}
\hline Active ingredient & Application & Dose ha ${ }^{-1}$ & Mechanism of action $^{\text {Ametrina }}$ \\
Cletodim & Pre- and post-emergence & $2-3,3 \mathrm{~kg}$ & Photosystem II inhibitor \\
Diuron & Pre- and post-emergence & $0,35 \mathrm{~L}$ & ACCase Inhibitor \\
Sulfentrazona & Pre-emergence & $2-4 \mathrm{~kg}$ & Photosystem II inhibitor \\
Bromacila + Diuron & Pre-emergence & $0,8-1,4 \mathrm{~L}$ & Protox inhibitor \\
Paraquat + Diuron & Pre- and post-emergence & $1-4 \mathrm{~kg}$ & Photosystem II inhibitor \\
Source:MAPA, Agrofit System, 2021 & Post-emergence & $0,4-2,0 \mathrm{~L}$ & Photosystem I and II inhibitor
\end{tabular}

Source: MAPA, Agrofit System, 2021.

The effectiveness of these products has already been proven in several scientific studies, although some regularly used, such as Diuron, for example, can cause phytotoxicity to plants if they are affected (Carvalho et al., 2018). Maia et al. (2012) evaluating the effects of manual weeding and application of the herbicides Diuron, Fluazifop-pbutyl and Atrazine + S-metolachlor in 'Pérola' pineapple crops, verified that these chemical agents do not affect the flowering time, yield and fruit quality, however, observed symptoms of phytotoxicity in plants submitted to the application of a mixture of Atrazine + S-metolachlor, indicating that these products are efficient, can be used throughout the cultivation cycle, but requires caution during applications.

Carvalho et al. (2018), studying the effects of Diuron at a dose of $7.5 \mathrm{~mL} \mathrm{~L}^{-1}$ on cultivars IAC Fantástico, Vitória, MD2 and Pérola also verified phytotoxicity status after application of Diuron, with temporary negative responses in $\mathrm{CO} 2$ assimilation, conductance stomatic, and efficiency in water use, and that the physiological responses were only fully recovered by the pineapple IAC Fantástico. Model et al. (2010) evaluating the efficiency of Diuron, Glyphosate, Diuron + Glyphosate and the mixture of Atrazine + Simazine in relation to manual weeding, found that Glyphosate, an unregistered product for pineapple, should be avoided, as it reduces natural flowering, the average weight of the fruits and the total productivity. The authors report that the other products tested are equivalent in terms of efficiency, not differing from manual weeding, and the most economical method should be chosen.

Valverde and Chaves (2020) mention that some herbicides used in pineapple cultivation can generate environmental problems and should be avoided. The authors cite as an example Bromacil, a highly mobile product in the soil, which can be absorbed by plant roots, causing phytotoxicity or leaching, contaminating groundwater (Jhala \& Singh, 2017). This product has already been banned in Costa Rica, the world's main producer (Valverde \& Chaves, 2020) but its sale is still allowed in Brazil (Agrofit, 2021).

With society's growing concern with the environment and preservation of natural resources, the need to adopt new sustainable production strategies, with a reduction in the use of agrochemical inputs, especially agricultural pesticides, becomes evident. In this context, the practice of ground cover with polyethylene-based mulching has been used as a viable strategy to control weeds and reduce the use of herbicides. This practice is already widely used in vegetable crops, and has been shown to be very promising for pineapple cultivation, especially in regions where 
water availability is low (Kader et al., 2017; Gao et al., 2019).

Mulching improves the microclimate of the root environment by reducing temperature variations and evaporation rates, increasing moisture retention in the system (Braga et al., 2017; Kader et al., 2017). In addition, its use effectively controls weeds, forming a physical barrier that prevents seed germination and plants emergence. Previous studies have verified other beneficial effects, such as reduction of nutrient losses by leaching, increased efficiency in water use, promotion in plant development, earlier harvests, fruits with better quality and higher productivity (He et al., 2018; Maia et al., 2018).

Pérez et al. (2005) evaluating the efficiency of mulching in three pineapple cultivars, Champaka, Oro and Smooth Cayenne Lisa, under uneven precipitation conditions in Veracruz, Mexico, verified that plants grown in soils with cover have higher dry mass production, greater leaf area and are photosynthetically more efficient. The authors verified that in the plantings under mulching, there was an increase in the average weight of the fruits by $0.1 \mathrm{~kg}$, reduction of acidity by $4.63 \%$ and increase in the contents of total soluble solids by 0.3 Brix, in addition to greater equatorial diameter of fruits and total productivity.

Sossa et al. (2017) mention that in pineapple crops, soil protection with mulching promotes changes in the physical, chemical and biological properties of the soil, with positive effects on vegetative development, enabling anticipating artificial floral induction, and consequently harvesting.

The use of dead cover, with cultural remains, or alive, with cover crops, is also a viable option, both for the control of invaders and for the protection and conservation of soil. This type of cover reduces the impact of rainfall drops and the drag of soil particles, nutrient losses and erosive processes, in addition to increasing organic matter in the system, improving the physical, chemical and biological characteristics of the soil (Sossa et al., 2017; Rose et al., 2019).

\section{Mineral nutrition}

Although the plant is considered rustic, tolerant to moderately acidic soils and with low fertility, the liming and fertilization is essential for obtaining high yields. Teixeira et al. (2020) informs that even being tolerant to moderate acidity levels, pineapple develops better in soils with $\mathrm{pH}$ around 5.5, and the dredging, with increased base saturation for ranges between 50 and $60 \%$ is essential to improve the root environment and supply the nutritional demand for calcium and magnesium.

In terms of nutritional requirement, nitrogen and potassium are the nutrients most required by pineapple (Omotoso \& Akinrinde, 2013). Cunha et al. (2020) evaluating the effects of nutrient omission in pineapple, cultivar BRS Vitória, found that only plants with nitrogen deficiency demonstrate visual symptoms, with new leaves presenting light green, while the other nutrients, even without visual symptoms, interfere in nutritional contents and vegetative and reproductive characteristics, such as diameter, length and weight of fruits.

Bonomo et al. (2020) investigated the effect of increasing doses of nitrogen (128, 256, 384 and $512 \mathrm{~kg} \mathrm{ha}^{-1}$ of $\mathrm{N}$ ) applied via fertigation on 'Pérola' pineapple, and four doses of potassium (192, 384, 576 and $768 \mathrm{~kg} \mathrm{ha}^{-1}$ ) of $\mathrm{K}_{2} \mathrm{O}$ ) in the edaphoclimatic conditions of São Mateus, Espirito Santo. The authors verified that this cultivar is highly responsive to fertilization, with increasing linear responses to nitrogen application, and that the dose of $498 \mathrm{~kg} \mathrm{ha}$ ${ }^{1}$ of $\mathrm{K}_{2} \mathrm{O}$ provides the highest yield of pineapple fruits, $66.9 \mathrm{t} \mathrm{ha}^{-1}$.

Rios et al. (2018) working with the cultivar 'Imperial' and increasing doses of potassium verified similar results for the conditions of the state of Paraíba, noting quadratic effect for potassium doses and that $410.4 \mathrm{~kg} \mathrm{ha}^{-1}$ of $\mathrm{K}_{2} \mathrm{O}$. The fruit and crown mass increases, length and diameter of infructescence and soluble solids content. The authors found that the dose of $285 \mathrm{~kg} \mathrm{ha}^{-1}$ nitrogen improves the physical and chemical characteristics of the harvested fruits, with increased soluble solids and titratable acidity.

In Bahia, in a dystrophic Yellow Argisol, Oliveira et al. (2015) evaluated the influence of four doses of nitrogen $0 ; 160 ; 320$ and $550 \mathrm{~kg} \mathrm{ha}^{-1}$ and four doses of $\mathrm{K}_{2} \mathrm{O}, 0 ; 240 ; 480$ and $600 \mathrm{~kg} \mathrm{ha}^{-1}$ on the vegetative and reproductive development of pineapple 'BRS Imperial', noting that potassium fertilization increases the mass, length and number of seedlings per plant linearly, while nitrogen positively influenced the emission of leaves and seedling mass. The authors observed that excess nitrogen fertilizer reduces the percentage of artificially induced flowering, while potassium increases flowering linearly.

Regarding phosphate fertilization, Cunha et al. (2020) observed that the deficiency of this nutrient reduces the diameter and length of the peduncle, causing lateral toppling of the fruits, dormancy of the lateral buds of shoots and reduction in the formation of seedlings, in addition to a reduction in the length and mass of the ' $D$ ' leaf in the occasion of floral induction.

Boron is the main micronutrient required by pineapple, and its deficiency can damage plant development and fruit formation. Cunha et al. (2020) observed that plants deficient in Boron occur a reduction of $14 \%$ in length and $11 \%$ in the diameter of the fruit stalk, causing toppling and exposing the pineapple to sunburn. They also observed reductions in length and thickness of sheet 'D' of 10 and $23 \%$, respectively, and in pulp firmness of $27 \%$ when compared to treatments well supplied with this element. Similar results had already been confirmed by Cunha et al. (2019) who verified reductions in 
fruit mass, juice volume and ascorbic acid content in Boron-deficient crops.

Teixeira et al. (2020) summarize that the amount of fertilizer applied in pineapple crops varies depending on the nutritional requirements of the plant; of the natural fertility of the soil and its nutrient supply capacity; of the technological level and the planting density; of the desired profitability and the local results determined through scientific research. Thus, consultation in manuals, books, technical documents and scientific articles, with specific information for the implantation region, such as Embrapa Production Systems, for example, is essential for the establishment of fertilization planning.

\section{Management irrigation}

One of the main characteristics of the pineapple is its adaptation to conditions of low water availability. This is because it is a plant with crassulaceous acid metabolism (CAM), which keeps the stomata closed during the day and $\mathrm{CO} 2$ fixation occurs at night, thus avoiding evaporative losses due to transpiration flow, improving the efficiency of water use, especially in the periods of drought (Carr, 2012; Couto et al., 2016). The plant needs 1000 to $1500 \mathrm{~mm}$ year-1 of well distributed rainfall, or $4 \mathrm{~mm}$ day-1 to achieve good yields (Santana et al., 2013).

The crop is resistant to rainfed cultivation, a system used mainly in small crops, however, there is a consensus among researchers regarding the responses to irrigation, as this practice complements the water demand of plants, especially in periods of drought, allowing optimal conditions for development even in long periods of drought (Silva et al., 2017).

Souza et al. (2007) observed that irrigation allows for standardization of fruits, staggering production and harvesting in the off-season, in addition to a second harvest, which increases productivity by up to $30 \%$ when compared to rainfed cultivation. Cunha (2009) mentions that in prolonged periods of drought, the pineapple reduces growth and does not respond satisfactorily to the application of flowering inducers, causing delays in flowering and harvesting.

Franco et al. (2014), in a trial with five irrigation depths (30, 50, 70, 100 and 150\% evaporation from the Class $A$ tank) applied to the 'Pérola' pineapple, in the municipality of Anaúba, Minas Gerais, found that irrigation, with replacement of 67.1 and $79.1 \%$ of the evaporated water, improves vegetative growth and natural flowering is greater with $70 \%$. In addition, the authors found that the production of seedlings per plant is greater with the irrigation depth corresponding to $85 \%$ of the evaporation of the class A tank.

In China, Feng et al. (2017) studying water levels applied in pineapple cultivation, with a control treatment (100\% of evapotranspiration), and two levels of water deficit $(50 \%$ and $25 \%$ of the control irrigation) found that water deficit significantly affects quality in fruits, with a reduction in total soluble solids. Silva et al. (2020) investigated the productive behavior of 'Pérola' pineapple subjected to replacement of $25,50,75,100,125,150$ and $175 \%$ of the crop evapotranspiration in the edaphoclimatic conditions of Alagoas, Brazil, noting that the crop has the best yields and quality of fruits when 100\% of the evapotranspiration water is replaced.

As seen, the crop is responsive to irrigation, however, excess water can compromise the vegetative development and fruit quality of the pineapple. Souza et al. (2009) found that increasing the water depth from 100 to $120 \%$ of the ETc compromised the firmness and titratable acidity of the fruits and that the soluble solids/titratable acidity ratio was altered, reducing the organoleptic qualities of the fruits. Similar results were observed by Silva et al. (2020), who found that the application of water depths above the evapotranspiration of the crop reduces the mass of fruits with and without crown, the length and diameter of the fruits, in addition to harming the qualitative characteristics of the fruits.

Almeida et al. (2002) summarize in their work the main recommendations for pineapple irrigation, stating that, in general, the crop needs a minimum amount of rainfall ranging from 80 to 100 $\mathrm{mm}$ month-1. They reinforce that irrigation is essential in regions where annual precipitation is less than $500 \mathrm{~mm}$, and even above this limit, irrigation is recommended if it occurs more than three consecutive months with monthly rainfall less than $15 \mathrm{~mm}$, or four with less than $25 \mathrm{~mm}$ monthly.

\section{Management floral induction}

Under natural conditions, pineapple flowering is slow and uneven, and occurs under conditions of short days and cold nights. To prevent this transition, from the vegetative to the reproductive phase, from occurring under inadequate conditions, the plants are induced to synchronize the floral differentiation by external ethylene treatments, a technique that allows to synchronize fruit formation and facilitate harvesting, in addition to being a strategy to stagger the production, so that the fruits are harvested at favorable times, when the supply of the product is scarce (Cunha, 2005; Kist et al, 2011).

The main plant regulators used in pineapple floral induction are calcium carbide $\left(\mathrm{CaC}_{2}\right)$ and Ethephon (2-chloroethylphosphonic acid) (Rezende; Kluge, 1998; Cunha, 2005). They are substances that differ from each other by the method of action, being mainly influenced by climatic conditions and factors inherent to the plant itself, such as nutritional status, age and vegetative size. $\mathrm{CaC}_{2}$ can be applied in solid form, at a dosage of 0.5 to $1.0 \mathrm{~g}$ plant-1, in rainy periods, or in liquid form, at 30 to 50 $\mathrm{mL}$ plant $^{-1}$. The recommendation for Ethephon is 1 to 4 liters of the commercial product Etrhel ${ }^{\circledR}$ for every $1000 \mathrm{~L}$ of water, with application of 30 to 50 $\mathrm{mL}$ of the solution per plant (Cunha, 2009). 
Phytoregulators promote increased ethylene production in the meristematic region of the plant and flowering occurs after changing the indoleacetic acid (IAA) content in this growing region (Cunha, 2005; Cunha, 2009). The vegetative development stage and plant age are relevant factors and directly reflect on the flowering rate and size of the fruit produced (Fassinou-Hotegni et al., 2015).

Several parameters described in the literature can indicate the ideal time for the floral induction procedure, such as the age, height and vegetative state of the plant, and the length of the "D" leaf, the largest and most physiologically active.
Souza and Reinhardt (2009) advise that the treatment of floral induction can only be carried out on well-developed plants, capable of nourishing and supporting the mass of the fruit, so that they reach the size required by the consumer market. The authors claim that fruit mass is directly correlated with plant size at the time of floral differentiation, and that more vigorous plants tend to produce larger fruit. In this way, researches with several cultivars were developed with the objective of determining the ideal moment for floral induction, based on the leaf length "D" (Table 2).

Table 2. Minimum leaf length " $\mathrm{D}$ " of different pineapple cultivars so that artificial floral induction can be performed.

\begin{tabular}{lcc}
\hline Cultivar & Leaf length "D" $(\mathrm{cm})$ & References \\
\hline BRS Quinari & 83 & Ritzinger, 1996 \\
\hline BRS Imperial & 63 & Sampaio et al., 2011 \\
\hline BRS RBO & 80 & Andrade Neto et al., 2016 \\
\hline & 77 & Silva et al, 2012 \\
BRS Vitória & 82 & Pegoraro et al., 2014 \\
& 64 & Küster et al., 2017 \\
& 63 & Silva et al., 2020 \\
\hline IAC Fantástico & 80 & Silva et al., 2020 \\
\hline Pérola & 80 & Rodrigues el al., 2010 \\
\hline Smooth Cayenne & 70 & Sampaio et al.,2011 \\
\hline
\end{tabular}

This information is important and should be taken into account when making decisions, as the early stimulus to flowering can produce small, lowquality fruits. Van de Poel et al. (2009) explain that pineapple is sensitive to the application of ethylene, even in the initial stage of development, around 3 months after planting, and although natural flowering does not occur during this phase, the induction of artificial flowering causes problems, since the plant does not have the size and vigor to develop the fruits to the minimum weight required by the consumer market.

\section{Final considerations}

The cultural treatments, carried out throughout the production cycle, affect the yield and quality of pineapple fruits. The management of weeds is essential to obtain high yields and mulching in crop lines is a viable alternative to reduce herbicide use and labor costs.

Pineapple is a plant tolerant to moderately acidic soils and with low fertility, but liming and supplemental fertilization, mainly nitrogen and potassium, ensures increased productivity and better-quality fruits.

Irrigation with water depths up to $100 \%$ of the crop's Evapotranspiration provides adequate conditions for vegetative and reproductive development, allowing to anticipate artificial floral induction and harvest. On the other hand, poor drainage and excessive soil moisture compromise plant development and fruit quality.

The artificial induction of flowering is an essential technique for commercial crops, allowing the synchronization of flowering, the staggering of production, in addition to facilitating the handling and harvesting process.

\section{References}

AGROFIT, Sistemas de Agrotóxicos Fitossanitários: Consulta de ingredientes ativos. 2021. Available in: <Ministério da Agricultura, Pecuária e Abastecimento>. Access 12 sep. 2021.

ALMEIDA, O.A. de; SOUZA, L.F.; REINHARDT, D.H.; CALDAS, R.C. Influência da irrigação no ciclo do abacaxizeiro cv. Pérola na área de tabuleiro costeiro da Bahia. Rev. Bras. Frutic. v. 24, n. 2, p. 431-435, 2002. https://doi.org/10.1590/S0100-29452002000200030

ANDRADE NETO, R. de C.; NOGUEIRA, S. R.; CAPISTRANO, M. da C.; OLIVEIRA, J.C. de; ALMEIDA, U.O. de. Recomendações técnicas para o cultivo do abacaxizeiro, cv. Rio Branco (BRS RBO). Comunicado Técnico 192, 2016. 10p.

BARTHOLOMEW, D.P.; MALÉZIEUX, E.; SANEWSKI, G.M.; SINCLAIR, R. Inflorescence and fruit development and yield. In: BARTHOLOMEW, D.P.; Paull, R.E.; Rohrbach, K.G. (eds.). The pineapple: botany, production and uses. Manoa, Honolulu, University of Hawaii, 2003. p. 167-202. 
BONOMO, R., ZUCOLOTO, M., SOUZA, J.M., MAGALHÃES, A.M. de P., BALDOTTO, P.H. de S. CAMPANHARO, A. Production and quality of 'Pérola' pineapple under fertigation. Emir. J. Food Agric., v. 32, n. 2 , p. 109-116, 2020. https://doi.org/10.9755 lejfa.2020.v32.i2.2072

BRAGA, M.B., MAROUELLI, W.A., RESENDE, G.M., MOURA, M.S.B., COSTA, N.D., CALGARO, M., CORREIA, J.S. Coberturas do solo e uso de manta agrotêxtil (TNT) no cultivo do meloeiro. Hortic. Bras., v. 35 , n. 1 , p. $147-153,2017$. https://doi.org/10.1590/ S0102$\underline{053620170123}$

CARR, M.K.V. The water relations and irrigation requirements of pineapple (Ananas comosus var. comosus): a review. Exp. Agric., v. 48, n. 4, p. 488-501, 2012. https://doi.org/10.1017/S0014479712000385

CARVALHO, A.R.J., MAIA, V.M., ASPIAZÚ, I., PEGORARO, R.F., OLIVEIRA, F.S. Physiological variables in pineapples submitted to the application of diuron. Planta Daninha, v.36, Epub, 2018. https:// doi.org/10.1590/S0100-83582018360100118

COUTO, T.R., SILVA, J.R., MORAES C.R.O., RIBEIRO, M.S., NETTO, A.T., CARVALHO, V.S., CAMPOSTRINI, E. Photosynthetic metabolism and growth of pineapple (Ananas comosus L. Merr.) cultivated ex vitro. Theor. Exp. Plant Physiol., v. 28, n. 3, p. 333-339, 2016. http://dx.doi.org/10.1007/s40 626-016-0062-x

CRESTANI, M., BARBIERI, R.L., HAWERROTH, F.J., CARVALHO, F.I.F. de; OLIVEIRA, A.C. de. Das Américas para o Mundo - origem, domesticação e dispersão do abacaxizeiro. Cienc. Rural, v. 40, n. 6, p. 1473-1483, 2010. https://doi.org/10.1590/S0103-84782010000600040

CUNHA, G. A. P. da. Applied aspects of pineapple flowering. Bragantia, v. 64, n. 4, p. 499-516, 2005. https://doi.org/10.1590/S0006-87052005000400001

CUNHA, G.A.P. da. Fisiologia da floração do abacaxizeiro. In: CARVALHO, C.A.L. de, DANTAS A.C.V.L., PEREIRA, F.A. de C., SOARES, A.C.F., MELO FILHO, J.F., OLIVEIRA, G.J.C. de. (Org.). Tópicos em ciências agrárias. Cruz das Almas: Universidade Federal do Recôncavo da Bahia. 2009. p. 54-75.

CUNHA, J.M., FREITAS, M.S.M., CARVALHO, A.J.C. de, CAETANO, L.C.S., PINTO, L.P., PEÇANHA, D.A., VIEIRA, M.E., LIMA, T.C., SANTOS, P.C.E. dos. Foliar content and visual symptoms of nutritional deficiency in pineapple 'Vitória'. J. Plant Nutr., 2020. https://doi.org/10.1080/01904167.2020.1849297

CUNHA, J.M., FREITAS, M.S.M., CAETANO, L.C.S., CARV ALHO, A.J.C. de, PEÇANHA, D.A., SANTOS P.C. dos. Fruit quality of pineapple 'Vitória' under macronutrients and boron deficiency. Rev. Bras. Frut., v. 41, n. 5, p. 1-10, 2019. https://doi.org/10.1590/0100-29452 019080

DJIDO, U.; HOTEGNI, N. V. F.; LOMMEN, W. J. M.; HOUNHOUIGAN, J. D.; ACHIGAN-DAKO, E. A. STRUIK, $P$. C. Effect of planting density and $\mathrm{K}_{2} \mathrm{O}: \mathrm{N}$ ratio on the yield, external quality, and traders' perceived shelf life of pineapple fruits in Benin. Frontiers in Plant Science, v. 12, 627808, 2021. doi:10.1088/1755-1315/81/1/012037

ESPINOSA, M.E.Á., MOREIRA, R.O., LIMA, A.A., SÁGIO, S.A., BARRETO, H.G., LUIZ, S.L.P., ABREU, C.E.A., YANES-PAES, E., RUIZ, Y.C., GONZÁLESOLMEDO, J. L., CHALFUN-JÚNIOR, A. Early histological, hormonal, and molecular changes during pineapple (Ananas comosus (L.) Merrill) artificial flowering induction. J. Plant Physiol., v. 209, p.11-19, 2017. https://doi.org/ 10.10 16/j.jplph.2016. 11.009

FAO, Food and Agriculture Organization of the United Nations. FAOSTAT Database. 2019. Available in: <http://www.fao. org/faostat/es/\#data>. Access em: 12 sept. 2020

FASSINOU-HOTEGNI, V.N., LOMMEN, W.J., AGBOSSOU, E.K., STRUIK, P.C. Influence of weight and type of planting material on fruit quality and its heterogeneity in pineapple [Ananas comosus (L.) Merrill]. Front. Plant Sci., v. 5, p. 798, 2015. https://doi.org/10.3389/fpls.2014.00798

FENG, H., DU, L., LIU, S., ZHANG, X. Effects of different deficit irrigation on sugar accumulation of pineapple during development. Earth Environ Sci., v. 81, 2017.

FRANCO, L.R.L., MAIA, V.M., LOPES, O.P., FRANCO, W.T.N.D., SANTOS, S.R. Crescimento, produção e qualidade do abacaxizeiro 'pérola' sob diferentes lâminas de irrigação. Rev. Caatinga, v. 27, n. 2, p. 132 -140, 2014.

GAO, H., YAN, C., LIU, Q., DING, W., CHEN, B., LI, Z. Effects of plastic mulching and plastic residue on agricultural production: A meta-analysis. Sci. Total Environ., v. 651, n. 1, p. 484-492, 2019. https://doi. org /10.1016/j.scitotenv.2018.09.105

HE, H., WANG, Z., GUO, L., ZHENG, X., ZHANG, J., LI, W., FAN, B. Distribution characteristics of residual film over a cotton field under long-term film mulching and drip irrigation in an oasis agroecosystem. Soil Tillage Res., v. 180, p. 194-203, 2018. https://doi. org/10.1590/S0100$\underline{29452010005000031}$

IBGE. Instituto Brasileiro de Geografia e Estatística: Censo Agropecuário. 2020. Available in: http://www.sidra.ibge.gov.br. Access in 15 aug. 2021.

JHALA, A.J., SINGH, M. Leaching of indaziflam compared with residual herbicides commonly used in Florida citrus. Weed Technol. v. 26, p. 602-607, 2017. https://doi.org/10.1614/WT-D-11-00161.1

JULIUS, I.P., TSENG, H.H., LIN, H.L. Low temperature effect on flower and fruit development of 'Tainug $n^{\circ} 17$ ' pineapple. Acta Hortic., n. 1166, p. 131-136, 2017. https://doi.org/10.17660/ ActaHortic.2017.1166.18

KADER, M.A., SENGE, M., MOJID, M.A., ITO, K. Recent advances in mulching materials and methods for modifying soil environment. Soil Tillage Res., v.168, p.155-166. https://doi.org/10.1016/j.still.2017. 01.001

KIST, H.G.K., RAMOS, J.D., PIOR., DOS SANTOS, V.A. Diquat e ureia no manejo da floração natural do abacaxizeiro 'Pérola'. Rev. Bras. Frutic., v. 33, n. 4, p.1048-1054, 2011. https://doi.org/10.1590/S010029452011000400002 
KÜSTER, I. S., ALEXANDRE, R.S., ARANTES, S.D., SCHMILDT, E.R., ARANTES, L.DE.O., BONOMO, R., KLEM, D.L.B. Influência da época de plantio e indução floral na qualidade de frutos de abacaxi 'Vitória'. Rev. Ifes Ciênc., v.3, n.2, https://doi.org/10.36524/ric.v3i2.324

MAIA, L.C.B., MAIA, V.M., MELO, LIMA, M.H.M.; ASPIAZÚ, I. PEGORARO, R.F.P. Growth, production and quality of pineapple in response to herbicide use. Rev. Bras. Frut., v. 34, n. 3, p. 799-805, 2012. https:// doi.org/10.1590/S0100-29452012 000300020

MAIA, V.M., ASPIAZÚ, I., PEGORATO, R.F. Sustainable weed control in pinepple. In: KORRES, N.E.; BURGOS, N.E.; DUKE, S.O. (ed.). Weed control: Sustainability, hazards and risks in Cropping systems worldwide. Boca Raton, FL: CRC Press (Taylor \& Francis Group), 2018. cap. 25. p. 470-484.

MATOS, A.P. de, VASCONCELOS, J.A.R., SIMÃO, A.H. Práticas de cultivo para a cultura do abacaxi no Estado do Tocantins. Cruz das Almas: Embrapa Mandioca e Fruticultura, 2014. 36 p. (Documentos, 211).

MODEL, N.S, FAVRETO, R. Comparação de custos de tratamentos de controle de plantas daninhas em abacaxizeiro cultivado no Rio Grande do Sul, Brasil. Pesq. Agropec. Gaúcha, v. 16, n. 1, p. 45-50, 2010.

MODEL, N.S., FAVRETO, R., RODRIGUES, A.E.C. Efeito de tratamentos de controle de plantas daninhas sobre produtividade, sanidade e qualidade de abacaxi. Pesq. Agropec. Gaúcha, v. 16, n. 1, p. 51-58, 2010.

NERI, J.C., MORI, J.B.M., VALQUI, N.C.V., HUAMAN, E.H., SILVA, R.C., OLIVA, M. Effect of planting density on the agronomic performance and fruit quality of three pineapple cultivars (Ananas comosus L. Merr.). Int. J. Agron., v. 2021, ID 5559564, 9 p. 2021. https://doi.org/10.1155/2021/5559564

OLIVEIRA, A.M.G., NATALE, W., ROSA, R.C.C., JUNGHANS, D.T. Adubação N-K no abacaxizeiro 'BRS Imperial' - II - Efeito no desenvolvimento e na floração da planta. Rev. Bras. Frut., v. 37, n. 3, p. 755-763, 2015. https://doi.org/10.1590/0100-2945-023/14

OMOTOSO, S.O., AKINRINDE E.A. Effect of nitrogen fertilizer on some growth, yield and fruit quality parameters in pineapple (Ananas comosus L. Merr.) plant at Ado-Ekiti Southwestern, Nigeria. Int. J. Agric. Res. v. 3, n. 1, p. 11-16, 2013.

PEGORARO, R.F., SOUZA, B.A.M.D., MAIA, V.M., AMARAL, U.D., PEREIRA, M.C.T. Growth and production of irrigated Vitória pineapple grown in semi-arid conditions. Rev. Bras. Frut., v. 36, n. 3, p. 693-703, 2014. https://doi.org/10.1590/0100-2945-265/13

PÉREZ, G. A., MBOGHOLI, A., SAGARRA, F., ARAGÓN, C., GONZÁLEZ, J., ISIDRÓN, M., LORENZO, J.C. Morphological and physiological characterization of two new pineapple somaclones derived from in vitro culture. In Vitro Cell. Dev. Biol. - Plant, v. 47, n. 3, p 428-433, 2011. https://doi.org/10.1007/s11627-011-9342y
PÉREZ, P.G., GARCíA, M.P.G., REBOLlEDO, L.M., URIZA, D.A., TINOCO, A.A.C., REBOLLEDO, A.M. Planting densities and plastic mulching for "Smooth Cayenne" pineapple grown in an aw2 climate fluvisol soil in Veracruz, México. Acta Hortic. Proceedings of the IV International Symposium on Pineapple, v. 666, p. 271275, 2005. https://10.17660/ActaHortic.2005. 666.30

REINHARDT, D.H. A planta e seu ciclo. In: REINHERDT, D.H.; SOUZA, L.F.S.; CABRAL, J.R.S. (Ed.). Abacaxi e produção: aspectos técnicos. Brasília: Embrapa Mandioca e Fruticultura. Brasília: Comunicação para Transferência Tecnológica, 2000. p. 13-14. (Frutas do Brasil, 7)

RENTON, M., CHAUHAN, B.S. Modelling crop-weed competition: Why, what, how and what lies ahead? Crop Prot., v. 95, p. 101-108, 2017. https://doi.org/10.1016/i.cropro.2016.09. 003

REZENDE, G.O., KLUGE, R.A. Abacaxizeiro. In: CASTRO, P. R. C.; KLUGE, R. A. Ecofisiologia de fruteiras tropicais: abacaxizeiro, maracujazeiro, mangueira, bananeira e cacaueiro. São Paulo: Nobel, 1998. p. $12-31$.

RIOS, E.S.C., MENDONÇA, R.M.N., CARDOSO, E. de. A., DA COSTA, J.P., SILVA, S. de. M. Quality of 'Imperial' pineapple infructescence in function of nitrogen and potassium fertilization. Rev. Bras. Cienc. Agrar., v. 13, n. 1, e5499, 2018. https://doi. org/10.5039/agraria.v13i1a5499

RITZINGER, R. Recomendação de cultivares de abacaxi para o Acre. Rio Branco, AC: Embrapa Acre, 1996. 2p. (Folder).

RODRIGUES, A.A.; MENDONÇA, R.M.N.; SILVA, A.P. da; SILVA, S. de M.; PEREIRA, W.E. Desenvolvimento vegetativo de abacaxizeiros 'Pérola' e 'Smooth Cayenne' no estado da paraíba. Rev. Bras. Frut., v. 32, n. 1, p. $126-$ 134, 2010.2 https://doi.org/10.1590/S0100$\underline{29452010005000031}$

ROSE, T.J., KEARNEY, L.J., MORRIS, S., ZWIETEN, L.V., ERLER, D.V. Pinto peanut cover crop nitrogen contributions and potential to mitigate nitrous oxide emissions in subtropical coffee plantations. Sci. Total Env., v. 656, p. 108117, 2019. https://doi.org/10.10 16/j.scitotenv.2018.11.291

SAMPAIO, A.C., FUMIS, T.de F., LEONEL, S. Crescimento vegetativo e características dos frutos de cinco cultivares de abacaxi na região de Bauru - SP. Rev. Bras. Frut., v.33, n.3, p.816-822, 2011. https://doi.org/10.1590/S0100-29452011005000101

SANTANA, M.J.D., SOUZA, O.P.D., CAMARGOS, A.E.V., ANDRADE, J.P.R. Coeficientes de cultura do abacaxizeiro nas condições edafoclimáticas de Uberaba, MG. Rev. Bras. Eng. Agric. Ambient., v. 17, n. 6, p. 602607,2013

SILVA, D.C.O. Leaf fertilization in nutritional supplementation of micropropagated pineapple cultivars. Investig. Agrar., v. 22, n. 1, p. 22-29, 2020. https://doi.org/10.18004/investig.agrar.2020.junio.22-29

SILVA, T.R.G.D., SILVA, J.C.D., LIMA, D.F., SANTOS, L.J.S., BARBOSA JÚNIOR, M.R., SANTOS, M.A.L. Productivity and fruit quality of 'pearl' pineapple as a 
function of irrigation depths. Braz. J. of Develop., v.6, n.6, p. 40140-40152, 2020 .

SOSSA, E.L., AGBANGBA, C.E., ACCALOGOUN, S.G.G.S., AMADJI, G.L., AGBOSSOU, K.E., HOUNHOUIGAN, D.J. Residues mmanagement practices and nitrogen-potassium fertilization influence on the quality of pineapple (Ananas comosus (I.) merrill) sugarloaf fruit for exportation and local consumption. Agronomy, v. 7, n. 26, 2017. https://doi. org/10.3390/agronomy7020026

SOUZA, C.B. de; SILVA, B.B. da; AZEVEDO, P.V. de. Crescimento e rendimento do abacaxizeiro nas condições climáticas dos Tabuleiros Costeiros do Estado da Paraíba. Rev. Bras. Eng. Agric. Ambient., v. 11, p. 134141, $2007 . \quad$ https://doi.org/10. 1590/S1415$\underline{43662007000200002}$

SOUZA, L.F. da S., REINHARDT, D.H. Abacaxizeiro. In: Crissóstomo, L. A.; Naumov, a. (Org.). Adubando para alta produtividade e qualidade - Fruteiras Tropicais do Brasil. Fortaleza, CE: Embrapa Agroindústria Tropical, 2009. IPI Boletim 18, p. 182-205.
SOUZA; O.P.D., TEODOROI, R.E.F., MELO, B.D., TORRES, J.L.R. Fruit quality and productivity of pineapple under different planting densities and irrigation levels. Pesqui. Agropecu. Bras., v. 44, n. 5, 2009. https://doi.org/10.1590/S0100-204X20090005 00006

TEIXEIRA, C.A.D., ROSA NETO, C., LEÔNIDAS, F. das C., COSTA, J.N.M., VIEIRA JÚNIOR, J. R., SILVA, F.de A.C., ARAÚJO, L. V. de, COSTA, R. S. C. da, ALVES, E. A., CARARO, D. C., ANDRADE NETO, R. de C., WADT, P. G. de O. Sistema de produção para a cultura do abacaxi no Estado de Rondônia. Porto Velho, RO: Embrapa Rondônia, 2020. 78 p.

VALVERDE, B.E., CHAVES, L. The banning of bromacil in Costa Rica. Weed Sci., v. 68, n. 3, p. 240-245, 2020. https://doi.org/10.1017/wsc.2020.13

VAN de POEL, B., CEUSTERS, J., De PROFT, M.P. Determination of pineapple (Ananas comosus, MD-2 hybrid cultivar) plant maturity, the efficiency of flowering induction agents and the use of activated carbono. Sci. Hort., v. 120 , n. 1, p. 58-63, 2009. https://doi.org/10.1016/j.scienta.2008.09.014 